TARBIYA: Journal of Education in Muslim Society, 2(2), 2015, 204-221

\title{
ISLAMIC RELIGIOUS EDUCATION IN THE ERA OF AFTA
}

\author{
Hasbi lndra \\ Ibn Khaldun University of Bogor, Indonesia \\ E-mail: hasbiindra58@gmail.com
}

Received: $13^{\text {th }}$ September 2015; Revised: $15^{\text {th }}$ October 2015; Accepted: $29^{\text {th }}$ December 2015

\section{Abstract}

Taman Pendidikan Al Qur'an (TPA), Pesantren and Madrasah Diniyah are important parts in the development of Islamic national education. Although the future of those Islamic education is quite difficult to be predicted, they have already become vital components of the national education system. In addition, the quality of this various Islamic institution is also leaded to the International standard education. This article is a qualitative research study which compare and contrast several literatures about Islamic religious education in Indonesia. ASEAN State of Education Report revealed that one of the 2013's agenda is to develop the quality of education in ASEAN countries. Based on this agenda, Islamic education, which is an important part of the educational system in Indonesia, is also hoped to increase its quality and be ready to compete in International level to face the AFTA. Several efforts have been devoted in order to increase the quality of Islamic religious education. This research is qualitative research study.

Keywords: Islamic religious education; AFTA

\section{Abstrak}

Taman Pendidikan Al Qur'an (TPA), Pesantren dan Madrasah Diniyah merupakan bagian yang penting dalam perkembangan pendidikan Islam nasional. Meskipun cukup sulit untuk diprediksi. masa depan pendidikan Islam tersebut sudah menjadi komponen yang sangat penting bagi sistem pendidikan nasional. Lebih lagi, kualitas institusi Islam yang beragam ini juga mengarah kepada standar pendidikan internasional. Tulisan ini merupakan penelitian kualitatif yang membandingkan dan membedakan beberapa literatur tentang pendidikan Agama Islam di Indonesia. Laporan Bagian Pendidikan ASEAN menunjukkan bahwa salah satu agenda 2013 adalah untuk mengembangkan kualitas pendidikan di negara-negara ASEAN. berdasarkan agenda tersebut, pendidikan Islam, yang merupakan bagian penting darui sistem pendidikan di Indonesia, juga diharapkan dapat meningkatkan kualitasnya dan siap untuk bersaing di tingkat internasional untuk menghadapi AFTA. Beberapa usaha telah dicurahkan untuk meningkatkan kualitas pendidikan agama Islam.

Kata kunci: pendidikan agama Islam; AFTA

How to Cite : Indra, H. (2015). Islamic Religious Education in the Era of Afta.TARBIYA: Journal Of Education In Muslim Society,2(2), 204-221. doi:10.15408/tjems.v2i2.2208.

Permalink/DOI: http://dx.doi.org/10.15408/tjems.v2i2.2208 


\section{Introduction}

Education is an important component in a country national development to face the future challenges. The future is difficult to be predicted, whether it will be good or no for this nation. Islamic religious education is a part of a khazanah for the better of Indonesia in the future. This educational institution has been regulated in a government regulation which mentions the existence of Islamic religious education and some are called Islamic religious education. The classification of Islamic religious education are formal and non-formal, in formal such as elementary and secondary, and for nonformal such as education in TKQ/TPQ, educational boarding schools and diniyah. In the non-formal education, there are not tiered education known as TKQ and also diniyah in islamic boarding school. There is also a tiered diniyah education which is held by people outside schools such as diniyah awaliyah, Wustha and Ulya. Islamic religious education has the goal to bring the best graduates in the interests of the nation and religion.Islamic religious education products can present and compete with another educational products.

Islamic religious education in its development has been in contact with various changes in the terms of the development of science and technology, cultural change, sociopolitical changes, economic changes and changes in appreciation of religion. These changes should already be predicted by Islamic education in order to anticipate the implementation of education.

Time is changing, the themes of life is no. The dynamics that occur so quickly, especially in the field of science and technology and cultural changes in society increasingly secular, hedonistic and consumerist. In addition, addressing the issue of Islamic religious education to form a qualified humans that can bring progress in human life. The guidance in terms of Islamic religious doctrines comprehensively encourage Muslim to present in the human quality. Presenting quality for Islamic religious education is the demands of the word of God that "Be the muslims who call to the good and forbid the bad" (QS. Ali-Imran, 110). It is a must that Muslim must have quality, it will be something ironic without it. Islamic religious education today will face between a country's trade policies with other countries in Asia called Masyarakat Ekonomi Asia (MEA). It looks like not directly related, but as an Islamic religious educational institutions that have been become a part of the national education system, it is a must to face the situation.

Posts related to Islamic religious education is still very rare especially when associated with AFTA era, this is a new moment will be applied to this December. Therefore this is an initial discussion paper. This paper will describe the development of Islamic religious education in the way, and now the institutions in the National Education System. The educational institutions are in the middle of globalization to the MEA's era, the era of free trade between countries of Asia which requires the quality of education of a country which compete in it. These institutions must adapt in order to prepare the students so that they have the knowledge and skills and these institutions must be managed with modern management.

\section{Islamic Religious Education}

Islamic religious education entirely is organized by society. This institution organized at the level of early childhood education as Taman Kanak-kanak Al-quran (TKQ) and Taman Pendidikan Al-Quran (TKQ) ${ }^{1}$, and Islamic boarding school and Diniyah education for adolescent.

${ }^{1}$ Well known as Kindergarteen. 
From the study of the history of Islamic religious education that have emerged in the community in Indonesia even since the beginning of the preachers spreading Islam in the country through teaching recite the Qur'an to their students, nowadays those educations are called TKQ or TPQ (Dit. PD. Pontren, 2013). This study simply takes place in the middle of the Muslim community. The place was originally at home or in the mosque and in the places where it was no longer adequate because of its limitations. Moreover, with a growing number of those who want to learn the Qur'an so that it was established a special place in the form of the building as their place of learning. In the beginning of this study using a model system of al-baghdadi with talaqqi, where students learn by meeting the teacher to listen the teacher then repeat what have been said by the teachers. On the following night, the same students meet the teacher then read about what have been learned in the previous night. Students will repeat at next night if they are not reading correctly (Dit. PD. Pontren, 2013).

This model of education has almost been evenly distributed throughout the country. Only later 1980s, this educational experienced the extraordinary dynamics. Education was developed in the classroom and stratified by age, the age of 4-7 years, in the kindergarten of AlQur'an, and 7-12 years in Taman Pendidikan Al-Quran. In these educations, students not only read the Qur'an but also memorizing short prayers like the prayer was about to eat and prayer for the parents. The development of this education in Indonesia was started by $\mathrm{KH}$. Dahlan Salim Zarkasyi who pioneered the establishment of kindergarten. In learning AlQuran, al-Mujawwidin Semarang in 1986 using the method qiraati, while KH. Human As'ad with Tadarus Angkatan Muda Masjid team and Mushalla Yogyakarta founded the kindergarten. The method used on 16 March 1988 was iqra', this is the starting of the dynamics of the education of Qur'an in the country and it is now grown throughout the country (Dit. PD. Pontren, 2013). The data of the education of AlQuran for 2012-2013 had 142285 institutions, the number of students was 8.469 .500 and the numbers of teachers was 72.004 . Those were great potential to prepare them to be a superior generation (Ditjen Pendis, 2014).

This education is very strategic because it is held at the beginning of the age of a human life so that the learning methods have been adapted with the times using the method of learning while playing which is different with the education afterwards. Education in this age of the early formation of the talents of the students in a variety of their potential. Many intelligences that can be implanted in this education, namely the intelligence to read, causing curiosity and the bases of creativity for development, and the establishment of early akhlakul karimah in the broad sense that includes discipline, honesty, responsible and so on, in addition to plant the base skill for life.

Another Islamic religious education is boarding school. Education is almost entirely set by the community. The boarding school education is "original" from Nusantara. Hasbi stated that educational institutions have existed at the time of Walisongo which were founded by Raden Rahmat in the 16th century in Gresik, East Java (Indra, 2009). Pesantren is derived from a combination of two syllables, namely sant (good man) and tra (like to help), so that the word means as a boarding school education to develop the human being a good person (Hamid, 1983). While Berg said that the word is derived from the word shastri or students shastra which means someone who mastered Hindu religious books which are related to science (Dofier, 1994). Pesantren which were originally grown in Java is currently developed also outside Java. In the of view Zamakhsjari Dofier, 
Education schools have four characteristics, there are mosques, kyai, students, and there are Turats as the material in pesantren (Dofier, 1994).

The beginning of the education is to examine religion carried porch cleric or religious scholars, and there is also reviewing religion conducted in mosques. But over time the mosque was not broad enough then made nearby a place to study religion. Learning religious clerics to many famous scientific invite those who live far, then it was made a dwelling for a period of time which is called pesantren education.

Pesantren not only gives the scientific but also can form the character of the students, such as by becoming honesty, discipline, teamwork, independent and others. They learned after dawn until 9 or $10 \mathrm{pm}$, which means that they learn at least for 16 hours. They were forbidden to watch TV or listen to the radio. They are therefore learn so much knowledge. Similarly, their morality good because good deeds are often socialized and get examples directly from kyai or ustacz or the change of the kyai. Students washed their own clothes and do their daily necessities alone so that they become independent and not easily to give up. Perhaps the cons of the learning in pesantren is the creativity of the students. Monolithic learning is not improving the creativity of the students (Indra, 2010). In fact, the nature of God is the Creator, then when in the human self, the nature of creativity to develop a form of God's creation on earth (QS. Ali.Imran, 190, al-Mukminun, 12).

In pesantren students learn to read the Qur'an with its tajwid. They also learn the science of religion through the guidance of a kyai and they generally have a reference through the Turats. They study about the problem of faith at the beginning, worship, and muamalah, then they study another lesson such as mantiq, balaghah, faraidl and other fields (Indra, 2010).

Studying Turats in pesantren is by its levels, from the beginning and then to the next level based on how long they are living in pesantren. The method that it used to study is sorogan, where students one-by-one directly come to the kyai then listening the reading and understanding it, and also through the way of bandongan, that is students learn to kyai in a group then write what have been said by kyai beside the writing or under the writing in the book. Another way is halaqah, where students study together, discuss a problem together to look for a solution (Indra, 2010). Studying religious at the time of colonization in pesantren is also used by the kyai to grow the spirit of the students to take the fight against the Dutch colonists. In their religious studies are encouraged to defend the oppressed, or do jihad, that is warring with an enemy that does colonization in the Nusantara.

In the colonial period, educational institutions that were established by the colonizers preparing the youth to work in the government administration were developed. The place where they learn in the classroom, there were levels or classes, in the subject area they studied general sciences such as arithmetic or algebra, biology, chemistry, where those subjects have been developed by Muslims during the Abbasiyah era. There were teachers who are specialized in teaching and to handle the administration. Students progress is also evaluated through repetition or evaluations in the end of the year, from this evaluation, the less intelligent students will be missed classes. The school graduates were given their diplomas and worked in government with enough salary, they had a bike and had a good house. The system that was applied by the colonizers influenced the education in the particular pesantren, especially in the subject matter, they not only learned 
about religion but also learned algebra , history and others. This is the substantive dynamic in pesantren (Azra, 1998).

In the development of pesantren that teach subjects Turats have ups and downs of its students, and then also it is necessary to improve the facility of the students. Thus, the managers of pesantren set up public schools which adopt the model of general education, by increasing religious education in the late afternoon or evening, beside that, they also set up the system of madrasah and a college of religion in pesantren, public college or university (Haedari, 2006). There are also students who live in pesantren but they study outside of the pesantren.They just study Turats in that pesantren with the kyai (Azra, 1998). From the dynamics of pesantren, it can be grouped into three types: first, pesantren of Salafiyah, where the students focus studying religion through Turats. There is also a pesantren that beside studying Turats, the students also attended formal schools like Junior/Senior High School or madrasah called the combination of Pesantren. There is also pesantren where the students studying religion and general knowledge, then Turats is not taught in pesantren of Khalafiyah or 'Asyriyah (Indra, 2010).

The pesantren of 'Ashriyah or modern originally stood in Ponorogo East Java and experiencing rapid development in the country. The students were given good language skills in English or Arabic. This language became the main thing for students so that students can communicate smoothly. In addition, the students were also studied leadership skills, writing skills, and others so that they can be mentally prepared to face various things in the community with their skills. This school had gained government recognition in the form of mua'dalah.
There is also pesantren that become a place to improve student' skill such as sewing, carpentry and so on. The potential that exists for the benefit of society is also improved, such as in the field of fisheries, agriculture, plantation. Those are becoming the experience of the students to life in the community.

Pesantren has been involved in national education as take part in the 9-year compulsory education organized in the pesantren of Salafiyah (Dit. PD. Pontren, 2007). Pesantren in the program package $A, B$ and $C$, which provide the opportunity for students beside to study the religion, they also study general knowledge and also they obtain a diploma equivalent to other public schools. With diplomas, they can work in the government or the public sector, or a servant of religion in society or continue their studies to the next level.

The government through APBN gives the funds to the development of pesantren. It based on its pesantren. Demands or the dynamics of the times necessary must be responded by a pesantren with a variety of changes in the management of education. Change is necessary and it is something that is lasting throughout the life of human, as long as it is something good. In the pesantren world has actually held the principle of al-muhafazhatu 'ala al-qadimi alSalih al-akhdzu wa al-jadidi al-ashlah/ keep the old one, and take the new one (Indra, 2010).

The existence of such rapid social change as a result of globalization has raised new challenges, not least for pesantren. Hence, pesantren as a social institution that has made a great contribution in the development of the spiritual life of the Muslim community, are required to be able to answer all the problems arising from the current social change.

There is the development of pesantren but very gradual and reactive. The best change requires planning and in-depth study on the 
future, where the development of the world is moving, and there pesantren is moved.

Pesantren, from year to year, growth until now. It has 160 thousand educators and 29.535 institutions and has 3,876,696 students as human resources that must be developed to prepare them to be human that have quality and useful for the nation (Ditjen Pendis, 2014).

Then, another Islamic religious education that Diniyah Education which was also born in the colonial period as diniyah which is held by pesantren and some community outside of pesantren. This education at that time received help from the Sultan as local authorities (Dit. PD.Pontren, 2007).

After Indonesian independence, Diniyah Education received support in BPKNIP edict on December 22, 1945 that in advancing education and teaching at least tried to be teaching at the sanggar, mosque, mosque and madrasah continue. Then in an effort to improve the quality of education Diniyah, it is pursued them with the Regulation of the Minister of Religion No. 31983 About Diniyah Madrasah curriculum which aims to improve the quality of education, so that the ideals of education on Diniyah education can be achieved selectively.

Religious Education was set up to accommodate Muslim children who are blind with their religion. There is a Diniyah Education in schools for students studying religion through the books which used Arabic. Then, Diniyah Education outside the pesantren, its students come from those who study in public schools but they are only study religious study 2 hours in a week, they learn in Diniyah. This study focused on studying Islamic sciences such as the science of tawhid, fiqh, tafsir-Hadith Islamic history and Arabic, this education is now called Diniyah Takmiliyah education. Education is meant to further enrich the knowledge of students about Islamic sciences and their application. This education in some areas such as areas in West Java, there is an emphasis by the Regional Regulation (Perda/Peraturan Daerah) that elementary school students to enter to junior high school to have a diploma Diniyah Takmiliyah Awaliyah. The curriculum that is taught in Diniyah has been adjusted by government policies that impose competencybased curriculum (Ishom, 2008).

In regard to the curriculum in the past, Diniyah Education in accordance with the decision of the Minister of Religion No. 3 1983, divides it into three levels, they are Diniyah Awaliyah, Diniyah Wustha and Diniyah Ulya. Then in 1991 the curriculum was developed into 3 types: (1) type A serves to help and enhance the achievement of the central themes of religious education in public schools, especially in terms of practice and exercise of worship and reading the Qur'an; (2) Type B works to increase the knowledge of Islam so that equivalent with Madrasah. Religious Education curriculum is oriented to the Government Elementary School, MTs and Madrasah Aliyah; (3) Type C functions to deepening religious by pesantren system. The learning material ranges from teaching the Qur'an, Akidah-Akhlak, Worship, Cultural History of Islam and Arabic (DIT. PD. Pontren, 2007).

Religious Education as well as other Islamic education in the middle of a global community whose development is very fast. They should also prepare themselves to enter this global era. For those who attend two schools, public schools and school Diniyah, so there is no gap between the understanding of the science of religion with generally accepted science students in formal school, then the teacher must have a scientific insight when explaining religious values.

Therefore, it is necessary to formulate an integrative curriculum based on competency. The quality of teachers needs to be improved 
through training. The teacher is generally guided by sincerity alone, and usually taught in many places, giving financial incentives to the teachers needs to be improved. Learning facilities and infrastructure are also very minimal, many of those who study in a place that is not feasible. If this education goes sober, then millions of students as the products of its education only have ordinary quality, they will be hesitant to face the life which is increasing more competitive, and they will become a burden on society or the government.

Currently, Diniyah Education increase very fast with the Regulation of the Minister of Religion No. 13 of 2014 on the Religious Education Islam that has divided Diniyah Education into Diniyah Takmiliyah and Formal Diniyah. Formal organization of Diniyah Education is organized in pesantren that carry the mission to create religious experts or scholars but received government recognition through a national examination formally.

Currently, Diniyah Education has as many as 4,143,604 students consists of students Ula, Wustha and Ulya with number of teachers 312.350 and the number of institutions 74.410 (Ditjen Pendis, 2013). Diniyah Education is mostly using class teaching methods, and also the graduates awarded a diploma, after graduation they can also pass on religious knowledge to a higher level.

Islamic religious education is currently in a point of education in the country that is also a part of the national educational measurement. The measurement of the level of education in Asia, the national education quality level is ranked at the bottom of Asian countries such as the following Table 1.
Table 1 . The quality of the education system and labor competitiveness of 12 countries

\begin{tabular}{llll}
\hline Countries & score & Countries & Score \\
\hline South Korea & 3.09 & Malaysia & 4.41 \\
Singapore & 3.19 & Hong Kong & 4.72 \\
Japan & 3.50 & Philippine & 5.47 \\
Taiwan & 3.96 & Thailand & 5.96 \\
India & 4.24 & Vietnam & 6.21 \\
China & 4.27 & Indonesia & 6.56 \\
\hline
\end{tabular}

The table shows how weak the competitiveness of Indonesian human resources if it compared to other Asian countries. Indonesia ranked under Thailand, Vietnam and Malaysia. Meanwhile, Indonesia was became the example of the development and the field of education by them. So that Indonesia should immediately undertake improvements, especially in the terms of management education in order to pass the best and qualified graduates. Measuring the quality of education is also indirectly describe education in general in Indonesia including Islamic religious education, as a consequence as part of the national education system.

Islamic religious education developed several strategies, they are the management must be oriented to the development of quality students. Competitions education in the era of free market or AFTA today's demanding the quality standards of education which are better which is able to enter to the segment of any country because of global agreement standard which allows it to be included for the developing countries like Indonesia. Good management of the education system will encourage the growth and the development of qualified human resources that can be positioned Indonesia in a better position, both regionally and internationally level. Improving management of the education system must of course be prepared to consider the potential of each area (Muhaimin, 2007).

By the paradigm of think locally act globally, Indonesia will be able to accommodate 
all the potential developments at the regional level, nationally and internationally by always siding with Islamic values platform morality as the basis of educational applications. Comparison of achievements in the field of access and quality of education for the Asia, Indonesia is under Japan and Korea is level 1, level 2 is Australia, Hongkong is level 3, level 4 is Thailand and Indonesia is the lowest in level 5. It shows that Indonesia only can promote itself at the lowest rank, below Japan and Korea, Australia, Hong Kong and Thailand is higher than Indonesia.

\section{Islamic Education Product and AFTA}

Islamic religious product is a product of education that has Islamic value that rahmatalillalamin, which sounds, Wama arsalnaka illa ramatan lil 'Alamin (QS. AlAmbiya, 107) Religious Education Islam brings God's mission as signed in the Qur'an, do not leave the weak generations (QS. Annisa, 9), it means that it is required a strong generation or have quality. Islamic religious education is also bring a mission of life that is in the diversity or plurality like the verse that reads: ya ayyuhannas inna khalaqnakum mindzakarin untsa waja'alnakum syu'uba wa wa qabaila lita'arafu (QS.al-Hujurat, 13) or it can be understood that Islam can give global benefit for all the human. In religious plurality stated by God that in the history of human life there are religious Jews, Christians (QS. Al-Baqarah, 256; al-Kafirun, 109).

Islamic outlook that sees life as a plurality of like seeing the colorful life that can be colored white ideal as a symbol of purity. The symbol of purity is Hudan that is derived from God who wants man to Hanif (QS.al-Baqara, 135), the top man of tawhid, the Oneness of Allah or follow the rules and leaving what is forbidden by him.
Since the beginning, the Prophet Muhammad had brought the message with infinite patience and continuing to provide Hudan but Hudan that is attached to a person's heart is God disposes. The Prophet smiled when facing the Quraysh in Makkah who insulted and continue in Madinah with Medina Charter agreement. Tolerant and open nature will bring graduates ready to face the diversity in their environment, and they will not easily to give up and set aside theirselves from the crowd.

Prophet behave gracefully because of his knowledge of deep insight, his knowledge is knowledge of God, the prophet practice the first verse of the Qur'an, its sound is iqra'. He liked reading, the prophet used to reading then repeat to read again when the word of God came to him and read verses kauniyat and "Charter of Medina" (Sjadzali, 1993) was appeared by one of them. The nature of nationality appeared to free its enemies when he controlled of the city of Mecca. The value of reading, reading anything that is well must also be inherited by Islamic religious education graduates.

The Prophet, not only read, but since he was young he worked, worked and worked, struggled with the problems that exist in society. The Prophet did not like Rishi who could say but could not work, to mobilize the community. This attiude that must be created in the era of Islamic religious education of present and future.

Muslims can be encouraged through AlQuran and Assunnah to have the quality of work in the face of world competition. Qur'an says Muslims must not give a mandate to those who are weak, (QS. Annisa ', 5, 9). About competence, of one implied by the Prophet in order to prepare the younger generation of Muslims, the hadith which means: "if a mandate is given to a person who not experts wait for its demise (Ismail, 1987). Thus, Islamic religious education must also prepare its graduates into 
the community of entepreneurship that has many opportunities for them. After graduate, they are able to create employment themselves and not depend on the other party.

The society now is an open global society. In this era, human interact within neno second. Sending and receiving information via email in a region that has no end. In this era, many television programs can be enjoyed by hundreds of millions of people with information of diverse valuable or otherwise. In this context Madjid says that the world is currently one workd one globe (Arifin, 2014).

Science and

$$
\text { technology }
$$

(IPTEK) development occurs through a number of international meetings held every years. Many discovery science and technology in fields of medicine, angkasa luar and others. The globalization of science and technology has reached all over the world and has been perceived its positive and negative. The progress of science and technology generated by educational institutions in the world in the West. In addition to the progress of science and technology has great benefits for humanity, the science and technology community is very helpful and easier to meet their needs (clothing, food, housing, learning, medical treatment and so on). But, the progress of science and technology also makes people becoming trapped in the "doomsday" generated by their own hands. Ozone problem, water contaminated by industrial waste, the gap between the rich and the poor, increasingly, and nuclear threat.

For that, there are six things that must be considered. First, science and technology policy should be integrated with national policy, science and technology is just only one part of the development policy of the nation. Second, Indonesia need the strategy to develop science and technology which are integrated and comprehensive, because science and technology can help the engineering in the development of an integrated and comprehensive nation. Thirdly, the issue of science and technology not only of national dimension but also an international dimension, then it is needed to handle it coherently. Fourth, with science and technology have led to diversity. Fifth, science and technology can bring conflict, but with diversity will bring creative synthesis, and the sixth, requires a basic attitude that we not only be reactive but also be proactive (Ibrahim, 1995).

In this global era, Muslims are entering the competition arena. Competition is often characterized by consumerism. This requires a foundation so that it can become a shield to face the competition of consumerism and able to face a reasonable life even in accordance with the cultural values and religion. An extreme example is the presence of excessive freedom, including sexual freedom and freedom of other negative life. So here shield mentality is very important. At the same time, competition is also related to the ability and achievement. Muslims need to be prepare theirselves to face this competition. Prepare the mental in the competition and at the same time prepare the human resource capacity to be able to compete, this will cover all aspects of life in terms of trade, services and others. Competition also requires self confidence (Azizy, 2004).

About globalization, one of the views that can be seen is the view of Akhbar Ahmad and Hasting, he gives the sense that globalization basically refers to the rapid development in communications technology, transformation, information that can bring parts of the world that is far that can be reached easily (Akbar S., 1994). Globalization is just a continuation of modernization which basically contains secularization that it is a continuation of the mission posmodemisme increasingly modern 
and secular, getting ahead and getting away from religion (Mas'ud, 2006).

On the other hand, globalization is a process of integrating the national economy to the world economic system beside democratization of governance, human rights and other central issues (Faqih, 2005). In the field of economic in the globalization is applicable the trade of liberalism (Furchan, 2006). It has started since the trade international agreement known as the GATT. Then NAFTA trade agreement between America with Mexico, and Sijori between Singapore, Johor and Riau Indonesia (Faqih, 2006). Liberalism, or more specifically, trade liberalization, can not be separated from capitalism and free markets that is likely to cause negative effects to the gap between the rich and non-rich (Faqih, 2006).

At the regional level will form the Asean Free Trade Association (AFTA) or ASEAN Economic Community (AEC). It was marked by several things. First, characterized by the countries in the Southeast Asia region will be used as a region unified market and production base as the flow of goods and services. Secondly, AFTA becomes economic region with a high level of competition, which requires policies which include competition policy, consumer protection, Intellectual Property Rights (IPR), taxation, and E-Commerce so that it will created a climate of fair competition; one of the ways is by improving the trading with online electronic media Third, AFTA will make this region has equitable economic development, prioritizing the Usaha Kecil Menengah (UKM) or Small and Medium Enterprises (SMEs). The competitiveness of UKM will be enhanced by facilitating their access to the latest information on market conditions, the development of human resources in the field of finance and technology. Fourth, AFTA will be integrated with the global economy. By building a system to improve coordination between the countries member will also enhanced participation of countries in the AFTA's global supply network for technical assistance to the less developed countries of ASEAN Member. It was to improve industrial productivity so that not only increase their participation in the regional scale but also raises the initiative to be integrated globally. The goal is to minimize the gap between ASEAN countries in terms of economic growth by increasing cooperation between them (Baskoro, 2014).

For Indonesia alone, AFTA will be a good opportunity because of trade barriers will tend to diminish. It will improve exports which in turn will increase Indonesia's GDP. On the other hand, it will appear a new challenge for Indonesia in the form of commodities traded homogeneity problems, for example for agricultural commodities, rubber, wood products, textiles, and electronics. In this case the competition risk will appear with the number of imported goods will flow in large quantities to Indonesia which will threaten the local industry to compete with foreign products of much higher quality. This in turn will increase the trade deficit for the State of Indonesia itself.

With the presence of this AFTA's event, it is expected to be more sensitive to the fluctuations which will occur in order to anticipate emerging risks appropriately. In addition, a slick collaboration between the state authorities and businesses is needed, both physical infrastructure and social (laws and policies) need to be addressed, as well as the need for increasing the capacity and competitiveness of energy and work opportunity and companies in Indonesia. Indonesia can not only be spectators in its own country in 2015 (Baskoro, 2014).

AFTA era became a direct challenge to Islamic religious education to prepare graduates so that they can compete with another 
educational products in Indonesia or overseas educational products. The key words of competition, higher education product is prepared to be a fighter amid in values are often at odds with the values of Islam, but they are still standing strong. Besides competence must be possessed by the graduates of Islamic religious education, today's era of domination Information technology (IT) (Nata, 2008). Another thing that needs to be prepared is also the self confidence to get along with the international community, the confidence not only because it has a myriad of knowledge or expertise but confidence since grown because they have the ability to communicate in the international language.

The teacher is a motivator, moving its student to be ready to fight. Do not let a teacher misses an opportunity to motivate, as the words man jadda wajad. Because God himself through the verses make motivation as a driver to Muslims as examples of people who have the knowledge to be raised in rank (QS.alMujadalah, 11), many other verses encouragement.

The values of Sufism should be minimized, because at their age is the age fighter must have the courage to live and demonstrate these Muslim who dared to compete with its competencies. Job somewhat easier for faculty in their midst provide the knowledge. In the context of language proficiency in a foreign language, sometimes nationalism is be asked by someone why should a foreign language? Foreign language, at least the communication language, Musims can spread the truth. Beside Arabic, the language of science to refer to the books of contemporary or classic books.

The teaching staff who study in abroad do not "hesitate" to share the knowledge to the students about English or Arabic. In fact, about the substance of their science could add from sources other readings. Which is expensive for them is a foreign language always hear from those who have the competence. Billingual language teaching using one of the alternatives that can do if it is done by the students who sufficiently prepared to compete with their peers who come from the Asian countries. In addition, to the teaching staffs are improving their language will be more fluent and sophisticated.

AFTA has been in sight, Islamic religious education like it or not have to deal with it. Therefore Islamic religious education that should give values to improve the students' quality to face and also prepare them for competition to face AFTA era. In addition, it must also prepare them to play an active role in the midst of the people who are still a lot of poverty and ignorance overwritten. People are waiting the Islamic religious educational products that assist and provide motivation to keep trying in the middle of their difficult life.

In addition to produce the quality of education can not help these institutions must be led by people who have visionary leadership that deliver quality. $\mathrm{He}$ is a leader who is always oriented towards changes in the quality of the students qualified. Leadership is involved together with his staff with motivation, directing and giving love on to the lower, all subordinates focused on improving the quality of satisfying its stakeholders, it should continue to improve themselves by training or through another lines (Sallis, 2006).

Islam as a blessing for all of nature, values accepted by human dignity. As a religion that demands to be light throughout nature, religious values should be the light of the life of the world. Islamic religious education should be driven by using all of the potential that exists in the human body through the totality of its management.

Islamic religious education should reflect the image of the majority of Muslim in this country. 
The amount that the majority do not like scum, many in number but do not give color to the way of the nation, when Indonesia Muslim is raised, it will show teaching authority in the eyes world and above another world ideologies.

\section{Islamic Religious Education and MEA}

Islamic religious education bears the mission of Islam as a religion of quality. This institution is no longer enough just as the preservation of religious values that is on the students, but they should be more than that. From the existing data of Islamic religious education students amounted to 15 million more, consisting of education Qur'an 8.469.500 students, students' pesantren 3.876.696 and students' diniyah 4,143,604, a very large amount as a potential in managing life. They can no longer be left in science and technology. Science and technology is the message of al-Quran (QS. Al-Jatsiyah, 13) that they should also be prepared. They will also meet and play with another human beings with foreign languages. To prepare them for Islamic religious education institutions should be managed professionally.

Islamic religious education with great potential that needed good management. Understanding the management, one of them is the setting (to manage), Allah has hinted in the verse: Yudabbbirul Amro minassamai fil ard thumma ya'ruju ilaihi bi Yamin kaana miqdaruhu alpha sanatin mimma ta'uddun (QS. Al-Sajda, 5) which means " He directs the whole affair from heaven to earth, then the matter was up to him in a day the measure of which is a thousand years of your counting". Then, in substance, one of them is to divide the authority to another, for example, God gave authority to the creatures called angels for duty recorded everything done by humans, whether it is good or bad through the angel Rakib and Atid. God gives authority to the angel Gabriel to convey the revelation in the form of verses of the Quran to the Prophet Muhammad. When Allah created man, He made a play by discussing with angels and demons.

In addition, one of the pillars of management is a leader, the leader in Islam called Khalifah (QS.al-Baqarah, 30) or raain. The verse that describes Khalifah in the letter of al-Baqarah, which means "man was created to be the leader/khalifah in the world". While raain said, in a hadith which states that "everyone is a leader will be asked about his leadership".

In the history of Islam, it can be traced from the journey of the Prophet Muhammad in leading the people full of dedication or totality. At night, he complained to God so many human beings receive the light of Islam and denounce his people to be the best people. But in the day, he was with the full totality of the lead among the people not just as people who give orders but he is directly involved in giving direction to the people. As a prophet he received the revelation of Allah in Makkah for the whole of humanity and in the city of Medina received a revelation to enhance the revelations he received in the city of Mecca. During his life, beside as a prophet, he is the leader of the country who he has made a law called the Medina Charter.

In his daily life, as a leader of state and leaders of the community, he is amanah in the perspective of modern management called accountable. He is tabligh in perspective of modern management briefing, he is fathanah who has planing and controlling, and he is siddiq, he is open or its leadership is participatory (Saputra, 2011). Leader who direct see and feel what happens in the middle of the his people. Its picture depicting various management functions such as planning, direction and control.

By affirming the vision of Islamic religious education visionary mondial or rahmatallil 
'alamin and has a mission to prepare students who qualified for their life and bring the mission to respond in a variety of issues in the coming era and its management is done with professional management that play a role in today's era of AFTA.

\section{Islamic Education Challenges in Facing the AFTA}

Recently, Muslims are entering the arena of global competition. Competition is often characterized by consumerism. The values of culture and religion are required as a foundation in order to face the competition of consumerism and also be able to face a reasonable life. An extreme example is the presence of excessive freedom, including sexual freedom and freedom of other negative aspects of life. Thus, mentality is very important. At the same time, competition is also related to ability and achievement. Faced to this competition. Muslims need to prepare themselves. Prepare the mentality for the competition and at the same time prepare the human resource capacity to be able to compete in terms of trade, services, and others. Azizy also strengthen this point by saying that competition also requires confidence (self-confidence) (Azizy, 2004).

Still on the globalization issue, Akhbar Ahmad and Hasting stated that globalization basically refers to the rapid development in communications technology, transformation, information that can bring parts of the world so much closer to each other and can be reached easily (Akbar S., 1994), Globalization is just a continuation of modernization which basically contains the contents of secularization which is a continuation of the pos modern SME mission that getting ahead and getting away from religion (Mas'ud, 2006).
On the other hand, globalization is the process of integrating the national economy to the world economic system in addition to the democratization of governance, human rights, and other central issues (Faqih, 2005). In the economic sector, the era of globalization has stimulated the trade liberalization (Furchan, 2006). It has started an international trade agreement, known as GATT. Then NAFTA, a trade agreement between America and Mexico, and the Sijori which is between Singapore, Johor, and Riau Indonesia (Faqih, 2006). Liberalism, or more specifically, trade liberalization, can not be separated from capitalism and free markets which could have disastrous negative effects of the gap between rich and non-rich (Faqih, 2006).

At the regional level, AFTA is being formed. It was marked by several things. Based on this agreement, the countries in the Southeast Asia region will be used as a unified region market and production bases of the flow of goods and services. Second, AFTA countries will become the economic region with a high level of competition, which requires several policies which include competition policy, consumer protection, Intellectual Property Rights (IPR), taxation, and E-Commerce. Several policies should be made to create a fair competitive environment; especially for a trade with onlinebased electronic media. Third, the AFTA will make this region has equitable economic development, prioritizing the Small and Medium Enterprises (SMEs). The competitiveness of SMEs will be improved by facilitating their access to the latest information about market conditions, the development of human resources in the areas of finance and technology. Fourth, the AFTA countries will be integrated with the global economy by building a system to improve coordination among the member states. It was to improve the productivity of the industry that not only 
increased the AFTA members' participations at the regional scale, but also led to the initiative to be globally integrated. The goal is to minimize the gap between ASEAN countries in terms of economic growth by increasing the cooperation between them (Baskoro, 2014).

In 2009, the 14th ASEAN in Cha-Am Hua stressed the importance of the contribution of education for the three pillars of ASEAN, namely political and security (the political and the security), economic, and socio-cultural. The previous leadership of ASEAN also adopted a blueprint of the ASEAN Socio-Cultural Community (ASCC), which proposes 28 actions that are relevant to education to be implemented by 2015 . It thus carried out as a joint commitment to improve the quality of education in the ASEAN region especially to face the AFTA (The ASEAN Secretariat, 2013).

For Indonesia, AFTA is hoped to create a good opportunity to diminish trade barriers among its member countries. It will increase exports, which in turn will increase the GDP of Indonesia. On the other hand, it will also emerging new challenges for Indonesia in the form of commodities, for example for agricultural commodities, rubber, wood products, textiles, and electronics (Santoso, 2008). In this case, the risk of competition will appear. The flow of numbered of imported goods in large quantities to Indonesia will become a threaten for the local industry. Indonesian product should also compete with foreign products that have much higher quality. This, unfortunately in turn, will increase the trade deficit for Indonesia.

On the investment side, this condition can create a climate that supports the entry of Foreign Direct Investment (FDI), which can stimulate economic growth through technology development, job creation, human resource development (human capital) and an easy access to the world market. Even so, it can also bring up the exploitation risk. Indonesia still has a low level of regulation that can cause a large-scale act of exploitation in the availability of natural resources by foreign companies into Indonesia. Furthermore, as the country with abundant natural resources, compared to other countries, there is also a possibility of exploitation by foreign companies that could damage the ecosystem in Indonesia. It is also the fact that the regulations of investment in Indonesia are not strong enough to keep the natural conditions, including the availability of natural resources (Republika Online, 2013).

From the aspect of employment, there are many job opportunities open to Indonesian people because of the various needs of its diverse membership. In addition, it is also a great opportunity for entrepreneurs to find the best workers in accordance with the desired criteria. But in terms of education and productivity, Indonesian workers are still unable to compete with foreign workers coming from Malaysia, Singapore, and Thailand (Republika, 2015).

Zuhdi pointed out that Indonesia has a low quality of human resources, especially in the aspect of education. It can be difficult for the community itself to compete with foreigner which are more competent in this ASEAN market (Zuhdi, 2014). In line with Zuhdi's opinion, Syamsuddin also believe that despite the well progress of current Islamic education, it has not performed optimally (Detik. 2016).

Regulation awareness in various aspects of Islamic educational institutions must start from stakeholders. Research by M. Fathoni revealed that there are three types of schools, namely; 1) Salafiyah (traditional) school, which is purely studying Islamic religious amounted to 14459 , or $53.10 \%$ 2) Khalafiyah (modern) school, in this type of boarding, the students are not only studied the Islamic religion, but also add science 
and general knowledge amounted to 7,727 , or $28.38 \%$. 3) the combination of acculturation religious curriculum, and a modern curriculum, but still keep the tradition salaf (traditions that belief long years ago) amounted to 5,044, or $18.52 \%$. All of the data were based on Indonesian MORA's data in 2013. The data also stated that most of pesantren leaders (approximately 85\%) had no college education. Meanwhile, there are only about $15 \%$ of those leaders have the S1 (bachelor) and S2 (masters) degree. The leaders' educational background then explained why most of the pesantren leaders have conventional thinking and slow response to the world changing (Hakim, 2014).

Based on this several reasons, Islamic religious educational institutions and governments must work together to find a solution regarding this problems. There are at least three ways that can be taken at this time to face the AFTA according to Zuhdi, first; the government should continue to facilitate and supervise Islamic schools and include it in the national education system without dictating Islamic schools in its implementation. Second; Islamic schools should immediately revise the curriculum by providing equal portions between the academic content materials and the religious tasks. Third; Islamic school teachers should improve their quality consistently. Fourth; introduce foreign culture to Islamic schools. Fifth; Islamic schools should also continue to improve academic performance in addition to the characteristics of Islam itself (Zuhdi, 2014).

The problems continues to the college level. Islamic education university still also finds many obstacles, one main problem is English language teaching. In a research study titled "Curriculum of Islamic Economics and Finance in Islamic University of Indonesia: Challenges of the Asean Economic Community" conducted by Ahmad Darmadji and Yuli Andriansyah, the findings of this study revealed that the Islamic university graduates tend to have a low level of English competence (Darmadji, 2014).

Based on several problems mentioned above, it can be concluded that Islamic education should still continue improving the quality of human resources, curriculum, system, teachers, teaching methodology, materials and of course, improve good cooperation with the government. Thus, the possibility of winning the AFTA "war" will be larger although there is no guarantee.

\section{Islamic Education Readiness to Compete in AFTA}

It is widely known that Islamic educational institutions in Indonesia are different from the existing Islamic educational institutions in other Southeast Asian countries and the world. Institutions' resilience and ability to evolve in accordance with the demands of the times have been proved by Islamic educational institutions in Indonesia, especially boarding school. Azra stated that pesantren is currently playing a very important role in the development of education in Indonesia. Not only as the center of Islamic education, but also as the center for the development and social empowerment. It can thus be seen today that, schools have had various program activities in the development of economic, social and technological. And even more importantly the pesantren has played its role as a center for civil society in the mediation to the government and all citizens (Azra, 2014).

Islamic religious education bears the mission to make Islam as a religion of quality. This institution is no longer simply as a place to preserve religious values which are grown on students, but it should be more than that. From the available data, the total of students of Islamic religious education amounted to more than 15 million students. There are 8.4695 million students noted as the students of Qur'anic 
education; 3.876 million students noted as pesantren students; and 4.143 million students noted as Madrasah diniyah students. Diniyah is one of the Islamic educational institution which expects to continuously provide Islamic education through the classical system. With this vast amount of students, they can no longer be underestimated.

Various efforts have been given to these Islamic religious educational institutions. Even various programs have been conducted jointly with other ASEAN countries through MORA and Ministry of Education and Culture (ASEAN State Of Education Report, 2013). The director of the ministry of religious schools, Mohsen, presented that at this time MORA will explore the potential of schools in entrepreneurship such as agribusiness and agro-industry, such efforts have been made ranging from mapping the potential of the school and its natural resources. According to Didi Hafidhuddin, boarding schools that can compete in the era of AFTA are schools that have curriculum skills such as agriculture, entrepreneurship, economics and so also the mastery of a foreign language. According to Didier, only private schools can implement such system and curriculum. Almost similar to Didier opinion, an economic observer of Islam, Gunawan Yasni said that, in order to face the AFTA, schools must provide a larger portion of the teaching of basic economic sciences and technologies (Republika, 2015).

Many pesantren contain several skills in its curriculum such as entrepreneurship, agriculture, livestock, fisheries and other skills that can provide ways to use potential of natural resources around the pesantren. Pesantren Darul Fallah Bogor is one of its good example because it has agricultural skills since 1960. It is also noted that PP Darul Fallah has recently improving the quality of the field (http://darulfallah.org). Other example is Pesantren al-Ittifaq Patuha-Bandung, that successfully applied skills in the field of agribusiness (Manshur, 2015). In addition, there is also pesantren Darul Falah Mungal Bendo, Sidoarjo, which develops skills in the field of economics. Until now pesantren Darul Falah Bendo, Sidoarjo own approximately 114 branch schools spreading throughout Indonesia (Yoyok, 2012). There are many more religious educational institutions who have been carrying out various efforts to improve the quality of the Islamic education system. All of this effort is not only for the sake of a better output to face the AFTA but also for Islamic educational purpose itself, that is to become useful human with superior quality of knowledge and skills, both in religion and in various other fields.

\section{Conclusion}

Islamic religious education has undergone a long journey. Islamic religious education generally established and managed by the private community or non government organization. Islamic Indonesian religious education are still exist until today and even growing largely in spite of all barriers of their development such as lack of funding. Worth noting is the pursuit of many alumni who plays in the community. Today after its successful in maintaining its existence, the next call is to prepare graduates to be able to respond to the challenges, such as AFTA. In this era, the competition for survival among Asian countries will continue in the next few years. We could not only be a spectator, but to play an active role in the community.

Islamic religious education is now living in a global world where many negative effects can be accessed easily through television and mobile phone. Islamic education alumny must present with his intelligence and roll up their sleeves to tackle the various problems that exist among the people. Muslim scholar can use IT and foreign language to benefit himself. By mastering English or Arabic, muslim scholars can actively 
involved in intercommunication between nations.

Muslim leaders with the vision of al-Quran should be at the forefront in creating high quality education. They should remind and direct the muslim scholars to get to it. They should hand in hand in developing high quality muslim scholars that will be able to compete with other educational products from other Asian countries. Thus, we can conclude that because of AFTA, competition between people in Asia can not be avoided. Muslim scholars must be ready to compete to be the best and decrease the cultural barriers in the world intercommunication.

\section{References}

Akbar, S. A., Donnan, H. (1994). Islam Globalization and Postmodernity. London:Routledge.

Arifin, S. (2014). Strategi pendidikan dalam rangka menghadapi globalisasi. TARBIYA: Journal of Education in Muslim Society, 1(2): 165-188.

Association of Southeast Asian Nations (ASEAN) (2014), ASEAN state of education: report 2013, ASEAN Secretariat, Jakarta, Indonesia, report prepared by M Hayden \& R Martin.

Azizy, Q. (2004). Melawan Globalisasi. Yogyakarta: pustaka pelajar.

Azra, A. (1998). Esei-esei Intelectual Muslim dan Pendidikan Islam. Jakarta: Logos.

Baskoro, A. (2014). Peluang, Tangtangan bagi Indonesia dengan Adanya Masyarakat Ekonomi ASEAN. Access at http://www.crmsindonesia.org/node/624

Dit. PD. (2013). Pontren, Pola pembinaan TKQ, Jakarta: Dit. PD. Pontren,

.(2013). Pedoman kurikulum TKQ/TPQ, Jakarta: Dit. PD. Pontren, 2013
(2007). Dinamika Pondok Pesantren di Indonesia, Jakarta : Dit.PD.Pontren, 2007 .(2007). Pola Pengembangan Madrasah Diniyah, Jakarta: Dit. PD. Pontren, 2007

Ditjen Pendis. (2014). Statistik Pendidikan Islam (2012-2013). Ditjen Pendis.

Dofier, Z. (1994). Tradisi Pesantren, Jakarta: LP3ES.

Faqih, M. (2006). Jalan Lain. Yogyakarta: Insist Press.

.(2005). Runtuhnya Teori Pembangunan dan Globalisasi. Yogyakarta: Insist Press.

Furchan, A. (2006). Transformasi Pendidikan Islam di Indonesia. Yogyakarta: Gama Media.

Haerdari, A. (2006). Panorama Pesantren Dalam Cakrawala Modern. Jakarta: Diva Pustaka.

Hamid, Abu. (1983). Sistem Pendidikan Madrasah dan Pesantren di Sulawesi Selatan. At Taufik Abdullah (ed.), Agama dan Peradaban Sosial. Jakarta: Rajawali Press.

Hasbi, I. (2010). Manajemen Pendidikan Islam. Tawazun, 4(4). Pascasarjana Univ. Ibn. Khaldun

.(2002). Pesantren dan Masyarakat. Majalah Ikhlas, 32(7) Depag RI.

(2009).Pesantren dan Peradaban. Jabal Hikmah, 2(4). STAIN Jayapura.

Ibrahim, M. D. (1995). Teknologi, Emansipasi dan Transendensi. Bandung: Mizan.

Ishom, M. (2008). Dinamika Madrasah Diniyah di Indonesia. Jakarta: Transwacana.

Ismail, A. A. Muhammad, B., J. (1987). al-Jami al-Sahih al-Mukhtasar. Beirut: Dar Ibn Katsir.

Mas'ud, A. (2006). Pendidikan Islam dalam Era Reformasi dan Globalisasi. Religia, 2. STAIN Pekalongan

Muhaimin. (2007). Tantangan dan Peluang PTAI Menuju Universitas Riset. Proceeding in Annual Conference on 
Islamic Studies. DIKTIS: Depag RI, Sjadzali, M. (1993). Islam dan Tata Negara, Pekan Baru Riau. Jakarta: UI Press.

Nata, A. (2008). Membangun Keunggulan

Thoyyib, M. (2007). Internasionalisasi Pendidikan Islam Indonesia, Jakarta: UIN Press.

Peraturan Pemerintah No. 55 tahun 2007

Rimbawan Y. (2012). Pesantren dan Ekonomi: Kajian Pemberdayaan Ekonomi Pesantren Darul Falah Bendo Mungal Krian Sidoarjo Jawa Timur. Conference Proceedings: AICIS XII, 5-8 November 2012.

Sallis, E. (2006). Total Quality Management in Education. Yogyakarta: IRCiSoD.

Saputra, A. (2011). Petunjuk Al-quran Dalam Memilih Pemimpin, http://riau1.kemenag.go.id/ index.php?a=a rtikel\&lid=472 accessed 23 April 2015. 